\title{
Influencing Factors and Countermeasure Analysis of the Development of Physical Education of Chinese University
} Xueshuang $\mathrm{Li}$

Zhuhai Institute of Jilin University, Guangdong Zhuhai 519041

\begin{abstract}
Through a research on the existing problems in the development model of physical education in Chinese university, several factors influencing the development of physical education in Chinese university have been discovered at present: PE teaching reform task in university, content setting and model using of university PE teaching; checkup and evaluation system of university PE teaching; teachers' quality of university PE teaching; environment of university PE teaching and so on. According to these problems, related countermeasure analysis is put forward to provide certain theoretical basis for our country's development and reform of university PE teaching.
\end{abstract}

Keywords: University PE teaching; Development; Countermeasure analysis

\section{影响中国高校体育教学发展的因素及对策分析}

\author{
李雪霜 \\ (吉林大学珠海学院, 广东珠海 519041 )
}

摘要: 通过对于中国高校体育教学发展模式中存在问题的研究, 发现目前影响中国高校体育教学发展的因素存在于几个 方面: 高校体育教学改革工作; 高校体育教学内容设置和模式使用; 高校体育教学考核与评价体系; 高校体育教学教师素质; 高校体育教学环境等, 根据这些问题提出相关的对策分析, 为我国高校体育教学的发展改革提供一定的理论依据。

关键词: 高校体育教学; 发展; 对策分析

引言

高校体育教学是中国高等教学模式中不可或缺的一部分, 是培养全方位、高素质人才的有机组成部分。 目前如何更好的利用高校体育教学模式, 完善高校体育教学体系已经成为中国高等教育面临的一个重要问 题。笔者通过对于中国高校体育教学发展模式中存在问题的研究, 发现目前影响中国高校体育教学发展的 因素，并根据这些因素提出相关的解决措施，以期为我国高校体育教学的发展改革提供一定的理论依据。

\section{1 目前中国高校体育教学发展存在的问题}

\section{1 高校体育教学改革工作脱离实际}

目前中国高校体育教学工作的重点仍然是体育技术教学, 这与世界体育教学强国美国、英国相比差距 巨大, 中国体育教学工作的旧模式以体育教学技能为主要方式, 片面的去追求体育教学知识的传播, 却忽 略了了对于中国大学生体育意识、体育能力等方面的教育培养, 这使得许多大学生在离开校园步入社会时, 也无法养成良好的体育锻炼的习惯, 高校体育教学的目的也就不得而终。

根据《2014 年全国学生体质与健康调研结果》显示: 中国学生整体体质与健康状况相比较于 2010 年 有所改善, 2014 年我国城乡学生身体发育水平持续提高, 城乡中小学生身体素质呈现稳步提高的好趋势; 但是, 我国高校大学生整体身体素质以及健康状况继续呈现下降趋势, 视力不良检出率仍然居高不下, 高 校大学生肥胖检出率持续上升。 ${ }^{1}$ 从这些角度我们可以发现中国大学生体质以及健康状况整体呈下降趋势, 
目前如何进行高校体育教学改革工作已经迫在眉睫。

\section{2 高校体育教学内容设置和模式使用缺乏创新}

中国高校体育教学内容设置和模式使用在最近几十年不断的改革发展, 但是陈旧观念以及体系的束缚 依旧制约着中国高校体育教学的现代化进程。目前中国高校体育教学的主要模式仍然是陈旧的苏联模式: “教师讲解一典型示范一学生练习一教师辅导一教师总结”, 绝大部分的中国高校都是通过这一模式来完 成既有的体育教学任务, 这一模式有利有弊, 虽然可以通过反复的训练达到锻炼身体的目的, 但是对于中 国大学生体育意识、体育能力等方面的教育培养却是没有涉及。同时这一模式主要是以教师为主导, 教师 传授为主要的方式, 学生被动的进行体育技能的学习, 这样的方式完全忽视了中国大学生身心的健康发展, 这也与我国高校教育提倡的: “以学生为中心”的观念背道而驰。

虽然最近几年中国高校体育教学课程模式进行了多次的改革创新, 例如在高校体育教学课程学习中加 入了专项体育教学和选修体育教学, 这对于丰富我国高校体育教学模式有着重要的作用。是由于资金、观 念、场地等多方面的限制, 改革中一些现代化健身器材、现代化体育教学观念的融入遇到了巨大的障碍, 这些都无法顺利的进入我国高校体育教学模式之中, 因此高校体育教学内容设置和模式使用的创新改革也 就无法实现。

\section{3 高校体育教师综合素质有待提高}

中国高校体育教学正在经历巨大的变革, 传统的增强体质的观念正在向健康发展转变, 这一思想观念 的转变更迫切的要求我国高校体育教学体系进行深化改革, 其中起到重要推导作用的就是高校体育教学的 实施者：体育教师群体。根据相关调查显示, 目前高校体育教学中做到以: “提高学生健康水平” 为目标 的比例仅仅占到 $37 \%$, 更多的教师在进行体育教学时仍然以掌握该项体育技能或者是完成某项教学指标为 根本目的, 认为只要完成体育教学的目标就可以完成高校体育教学的课程目的, 却忽略了了对于中国大学 生体育意识、体育能力等方面的教育培养, 这使得许多大学生在离开校园步入社会时, 也无法养成良好的 体育锻炼的习惯, 高校体育教学的目的也就不得而终, 这些错误陈旧的观念都在制约着我国高校体育教学 的现代化发展。

高校体育教学本应该是一项生动而又活泼的一项课程, 学生可以通过这一课程释放身心, 但是由于某 些教师的教学水平落后、教学方式单一, “教师讲解一典型示范一学生练习一教师辅导一教师总结” 这一 传统模式使得高校体育教学变得枯燥单一、缺乏乐趣。这样的体育教学对于刚从高中毕业, 对于任何新鲜 事物有着巨大兴趣的大学生而言就显得过于的束缚, 从体育兴趣、体育观念培养的角度来说都是极为不利 的。同时这种强制性、被动型的体育教学模式在中国高校普遍的存在, 甚至主导着我国高校体育教学的课 堂, 这与 “学生为中心”、“终身体育与健康” 这些新时代的观念都是背道而驰的。

最后, 目前我国高校体育教学课程研究规划落后先进国家较多, 高校体育课程往往作为所有课程研究 的末端, 被许多高校所遗弃, 这种状况严重制约着我国高校体育教学教师的教学创新能力以及教学课程研 究规划能力, 因此一部分的高校体育教师安于目前的教学现状, 认为按部就班的进行体育教学, 完成既定 的教学任务就是对学生最好的负责, 这也导致了我国高校体育教学工作与具体实践严重脱节。

\section{4 高校体育教学设施的配置亟待完善}

古语有言: 巧妇难为无米之炊。体育教学设施对于高校体育教学的重要性也就不言而喻了, 目前我国 
高校体育教学过程中体育设施的不完善已经成为我国体育教学中比较薄弱的一环。根据有关资料显示目前 为止我国高校体育教学中体育设施配置不完善较为常见, 只有某些国家级重点高校或是名校, 体育教育基 金相对较多，有足够的资金去完善体育教育设施配置方面的问题，但是随着我国大学生数量的逐年上涨， 众多学校进行扩充招新与此同时却没有下拨更多的专项资金, 这也就导致了学校体育场更加的拥挤、体育 设施破旧老化、体育设施远远落后于体育教学的发展。

目前, 中国体育教学改革发展正常向现代化、信息化迈进，在一些高校体育教学课程中，不仅仅需要 足够的场地与配置设施, 还需要一些现代化的多媒体信息技术去支持, 这要可以更好的去表达体育技术动 作以及战术的演练, 这些方面的进步都需要相应的多媒体的设备去支持, 如何去进一步完善这一方面设施 的缺失, 将会是我国高校体育教学面临的重要问题。

\section{2 高校体育教学发展的对策分析}

\section{1 提高我国高校体育教学发展的管理水平}

所谓的管理水平就是对于已有资源进行计划、组织、调控, 以实现预期目标的行为, 管理行为是人类 最重要的行为之一。高校体育教学管理水平的提高对于目前提高我国高校体育教学层次有着至关重要的作 用, 体育教学管理是一项十分考验学校综合能力的工作, 它需要学校可以协调学校不同管理部门之间的关 系, 及时解决好学生与教师工作之间的问题, 创造出更加优秀的教师工作环境, 以期提高高校体育教学的 水平。

目前高校体育教学管理工作主要是分为: 高校体育教学计划管理、高校体育教学质量管理、高校体育 教学秩序管理、高校体育教学档案管理等方面。由此我们发现高校体育管理工作的层次是较为清晰的, 不 同管理方面共同去组成了高校体育教学管理工作，这也就决定了其是一个会受到各项因素影响的综合动态 管理系统, 学校只有做到统筹这四个方面的工作, 及时的去处理来自这四方面的信息反馈, 并积极的解决 这四个方面之间的问题，才可以真正的去做好高校体育教学管理这一项复杂的工作。目前许多高校在进行 学生的扩充之后, 学生人数急速扩大, 但是设施器材却无法跟进, 这也就需要更加合理的安排体育教学的 时间地点、人数场地之间的问题, 才可以保证教学活动的正常实施。同时学校还可以提倡学生自主去开发 成立各项体育运动组织团队、并适当的给予资金场地等方面的支持，为学生去培养良好的体育锻炼意识， 同时学校还应该积极的开展各项体育赛事, 形成良好的体育锻炼氛围, 促进高校体育教学的不断进步发展。

\section{2 树立正确的高校体育教育观念}

高校体育教学观念是体育的社会存在的必然产物、是体育现象的客观现实在人们头脑中的反应。目前 我国高校体育教育必须要抛弃以往传统陈旧的教学观念, 去建立适应于现代高校体育教学的全新观念, 必 须更快的在社会健康观念和社会体育观念的基础上建立全新的体育教育观念以更好的引导高校体育教学 的发展。随着当今时代社会文化的高速发展, 我国居民对于健康内涵的认识有了本质上变化, 因此我国高 校体育教学观念也应该随之转变去适应如今的社会, 因此 “以人为中心”、“以素质教育为核心” 的新型 高校体育教育观念已经成为当今社会之主流。

传统的高校体育教育观念主要是以体育技能的传授为主要的方式，这一模式有利有弊，虽然可以通过 反复的训练达到锻炼身体的目的, 但是对于中国大学生体育意识、体育能力等方面的教育培养却是没有涉 及, 时这一模式主要是以教师为主导, 教师传授为主要的方式, 学生被动的进行体育技能的学习, 这样的 
方式完全忽视了中国大学生身心的健康发展。因此高校必须要培养学生终身锻炼的观念, 着重于培养学生 的健康观念：第一，将体育技能传授、科学锻炼方法等有机的结合，旨在培养终身锻炼观念；第二、不仅 仅只注重知识技能的传授，还需要培养学生的创新能力; 第三、立足于现实并着眼于未来，让大学生可以 在步入社会后依然有良好的健身习惯。

\section{3 提高高校体育教师的综合素质}

为了适应高校体育教育改革深化的需要，我国高校体育教学教师的综合素质必须得到进一步提升，只 有打造出适应当今时代的专业高校体育教师集体才可以更好的推进我国高校体育教学的改革完善。“教师 者, 传到授业解惑也”, 以为优秀的体育教师对于高校体育教学的发展可谓是至关重要, 第一、着重培养 高校体育教师的自主创新精神, 是目前高校体育教师综合素质一环的重中之重, 创新乃是进步之魂; 第二、 相关部门以及高校需要加大对于高校体育教师培养的专项经费, 制定出合适的体育教师进修计划、培训计 划, 以期更好地培训出优秀的教师群体; 第三、在不断建设高校体育教师团队时, 需要注意体育教师学术 水平以及科研能力的提高。

\section{4 不断优化高校体育教学环境}

“工欲善其事、必先利其器” , 在高校体育教学的环境就是所谓的：“器”，体育教学的硬件环境从 客观上决定了高校体育教学的质量, 所以我们必须要不断优化高校体育教学环境, 为我国高校体育教学的 进步发展创造出一个有力的条件。第一、高校需要加大对于体育教育经费的投入，加强学校体校教育的硬 件设施的改良, 从最大程度上保证体育教学的配置设施、场地经费达到适应教学的程度; 第二、各高校需 要设置更多更完善的体育项目作为体育教学的目标对象, 并做到扶持主要项目为重点, 对足球、篮球、乒 乓球、羽毛球等项目进行项目规划设计; 第三、此外高校还应配备相应的现代信息技术设备，合理利用多 媒体教学使学生在轻松活泼的氛围中掌握体育技能培养浓厚的体育兴趣, 培养学生终身体育锻炼的良好习 惯。

\section{参考文献：}

[1] 刘红梅, 刘家党. 影响我国高校体育教学发展的因素及对策分析 [J]．鸭绿江(下半月版)．2016(11)

[2] 舒刚民． 我国高校体育教学改革的影响因素及其发展对策研究 [J]．玉林师范学院学报．2013(02)

[3] 李科峰. 影响我国高校体育教学发展的因素及对策研究 [J]．齐齐哈尔师范高等专科学校学报. 2013(01)

[4] 王光军. 《国家学生体质健康标准》下的高校体育教学模式的研究 [J]. 当代体育科技. 2015(29)

[5] 程斌鹏． 现阶段高校体育教学存在的问题及改进策略探讨 $[J]$. 吉林省教育学院学报. 2016(03)

[6] 罗陵. 高校体育教学发展影响因素探究[J]。当代体育科技. 2016(32)

\section{References:}

[1] Liu Hongmei, Liu Jiadang. Factors Influencing the Development of Physical Education in Colleges and Universities in China and the countermeasures [J].Yalujiang Literature Monthly (Second Half).2016(11)

[2] Shu Gangmin. Factors Affecting the Teaching Reform of College Physical Education in China and Its Development Countermeasures [J].Journal of Yulin Normal University,2013(02)

[3] Li Kefeng. Factors Influencing the Development of College Physical Education in China and countermeasures [J].Journal of Qiqihar Junior Teachers' College.2013(01)

[4] Wang Guangjun. Study on Sports Teaching Pattern in Colleges and Universities Under the National Health Standard of Students [J].Contemporary Sports Technology,2015(29) 
[5] Cheng Binpeng. Problems and Countermeasures in the Teaching of College Sports Discussion in China [J].Journal of Educational Institute of Jilin Province.2016(03)

[6] Luo Ling. Study on Influencing Factors of the Development of Physical Education in Colleges and Universities [J].Contemporary Sports Technology.2016(32) 